\title{
ADMINISTRATIVE AND LEGAL REGULATION OF BANKING SYSTEM IN UKRAINE AND FOREIGN COUNTRIES
}

\author{
Dmytro Zhuravlov' \\ Research Institute of Public Law, Ukraine \\ Valeria Riadinska ${ }^{2}$ \\ State Research Institute of the Ministry of Internal Affairs of Ukraine, Ukraine \\ Yevhen Durnov ${ }^{3}$ \\ National Academy of Internal Affairs of Ukraine
}

\begin{abstract}
The purpose of the article is to conduct a comparative analysis of the administrative and legal principles of the functioning of the banking system of Ukraine and foreign countries and to determine on this basis ways to improve domestic legislation in this area. The subject of the study is world experience in the field of state regulation of the banking system. Methodology. The study is based on a comparison of foreign experience in the legal regulation of the functioning of the banking system on the example of the USA, Great Britain, Japan, Germany, and France with the current state of the state regulation of the banking system in Ukraine. Due to the use of the arsenal of general scientific and special-scientific methods and techniques of scientific knowledge, the content of administrative and legal regulation of the banking system under conditions of reorientation of the country's economy from the planned form to the market one, liberalization of foreign economic relations, strengthening of integration and globalization processes in the international financial and commodity markets was characterized and determined. Results of the comparative legal study showed the inefficiency and excessive "transparency" of the national model of the administrative-legal regulation of the banking system in comparison with foreign systems, as well as the imperfection of the legal and regulatory framework for its functioning. Practical implications. Administrative and legal principles of functioning of the banking system in certain foreign countries reflect the greater effectiveness of the mechanism of its state regulation in comparison with Ukraine. In most countries, this mechanism is oriented to the distribution of regulatory and control powers between the central bank and other government departments, which, in turn, reduces the risk of administrative pressure on individual banking institutions and the banking system as a whole. It is expedient to include this experience in the legal system of our state in order to increase its economic stability. Value/originality. A comparative legal study of world experience in the administrative and legal regulation of the functioning of the banking system of Ukraine and foreign countries provides a better understanding of prospects for the development of national administrative legislation in this area.
\end{abstract}

Key words: administrative and legal regulation, banking system, foreign experience.

JEL Classification: M1, G24

\section{Relevance}

Ukraine's acquisition of independence was an initial step towards the evolution of our state and also led to its accession to the world community. The country obtained an opportunity to develop as a social, democratic state, where securing the rights and freedoms of citizens is one of the main prerogatives. At the same time, there was a situation where the regulation in certain spheres of vital activity of society was considerably complicated as a result of the rapid change in the vector of the functioning of the state apparatus, the legal system, etc. For example, a large number of problem points arose in the financial sector of the state, namely, the construction of the banking system. The reorientation of the country's economy from the planned to the market form has necessitated the development of a fundamentally new

\footnotetext{
Corresponding author:

${ }^{1}$ Research Institute of Public Law.

E-mail:ndz0909@gmail.com

ORCID: 0000-0002-2045-9631

${ }^{2}$ State Research Institute of the Ministry of Internal Affairs of Ukraine.

${ }^{3}$ Department of History of State and Law, National Academy of Internal Affairs of Ukraine
} 
model of legal regulation and practical coordination of the entire array of banking institutions. In this regard, the issue of administrative and legal regulation of the banking system has acquired a high level of relevance in the legal environment.

At the same time, one should not forget that in recent years the development of our state is entirely aimed at joining the European environment, which requires a large number of reforms in various areas of Ukraine's functioning, in particular, the banking system. In this context, a scientific analysis of foreign experience in the field of state-legal coordination of this category is appropriate for the purpose of its further implementation within the framework of the national legal system. On the basis of this thesis, we believe it necessary to consider the peculiarities of the administrative and legal regulation of the banking system in Ukraine and foreign countries.

\section{The degree of development}

Different aspects of the administrative-legal regulation and activity of the banking system as an independent financial-legal category were investigated in the works of many domestic and foreign scholars such as: Aharkov M.M., Adamyk B.P., Andriiko O.F., Bernaziuk Ya.O., Voronova L.K., Hetmantsev D.O., Starynskyi M.B., Lavrushyn O.I., Kovalchuk A.T., Kostiuchenko O.A., Orliuk O.P., Shamrai I.A., Shemshuchenko H.Yu., and others. Instead, a proper scientific review of the foreign experience of administrative and legal regulation of the banking system was not carried out by scientists.

The purpose of the article is to conduct a comparative analysis of the administrative and legal regulation of the banking system in Ukraine and foreign countries.

\section{Presentation of the main material}

Administrative-legal regulation of the banking system is a complex legal mechanism, which constitutes a large number of legal rules. At the same time, the mechanism itself is a kind of classical category of legal regulation, which largely determines its specificity.

Note that in the dictionary literature, the term "regulate" is interpreted as:

1) to order something, manage something, subordinating it to the relevant rules, to a particular system;

2 ) to demand the normal operation of the machine, installation, mechanism, to ensure the coordinated interaction of the components, parts (Bilodid, 1977; Explanatory Dictionary of Contemporary Ukrainian Language, 2005).

In the Legal Encyclopaedia, edited by Shemshuchenko Yu.S., the category of legal regulation is defined as one of the main means of state influence on social relations with a view to organizing them in the interests of man, society, and the state. It is a kind of social regulation. The subject of the category are relations, the ordering of which is impossible without the use of the law. In addition, the author emphasizes that legal regulation has the expression in the form of a mechanism, the constituent elements of which are: the rules of law, legal facts, actually legal relations (social relations, mediated by the rules of law), acts of realization of rights and obligations of subjects of social relations and legal sanctions used to violators of the rule of law (Shemshuchenko, 1998). It should be noted that the definition described characterizes the category of legal regulation in general. Instead, administrative law is one of its varieties, which acquires its own particularities in connection with its membership in a particular legal field.

When analysing the content of the administrativelegal regulation mechanism, it is expedient to indicate that, in accordance with the Great Interpretative Dictionary of Modern Ukrainian Language under the general editorship of Busel V.T., the term "administer" is interpreted as bureaucratic management, with orders and instructions, instead of specific (Busel, 2005). That is, it is about the presence of a power, management aspect within the legal regulation. In addition, the phrase "administrative-legal" shows that the mechanism of legal regulation of this type is carried out through the legal rules of the administrative branch of law. The latter, according to Alforov S.M., Vashchenko S.V., Dolhopolov M.M., and Kupin A.P. - a branch of law (a set of legal rules) that regulates, in order to fulfil tasks and functions of the state, public relations of a managerial nature, which consist in the sphere of executive power, the internal organization of other state bodies, as well as in the process of implementation by public organizations, their bodies of external legal-power authorities (Alforov, Vashchenko, Dolhopolova, Kupin, 2011).

In the scientific environment, there are a large number of views on the content of specifically administrativelegal regulation. For example, Malko A.V. believes that the latter - a system of legal means organized in the most consistent manner in order to streamline public relations and promote the satisfaction of interests of subjects of law (Malko, Matuzov, 2004). According to Holosnichenko I.P., it is necessary to understand the mechanism of administrative-legal regulation as the totality of administrative and legal means, by which there is the influence on relations arising in the process of implementation of executive power (Holosnichenko, Stakhurskyi, 2005). Quite meaningful as regards to the characteristics of administrative-legal regulation is the approach of Kozlov Yu.M. He notes that this mechanism is characterized by legal means of regulatory type, that is, the regulations (including prohibitions), which find their direct expression in the fact that one of the parties to the regulated relationship has been given a certain amount of legally binding powers addressed to 
the other party. That is, it is a form of legal mediation of relations, in which one of the parties acts as a manager (the subject of management), and the other - who is managed (the object of management) (Kozlov, 2002; Khomiachenko, Yeriashov, 2014). In turn, Lazarenko V.A. to a certain extent shares this opinion. In defining the essence of the administrative and legal regulation of environmental security, the latter emphasizes that it is an integral part of public administration exercised by authorized state bodies, local self-government bodies, and the public, whose authorities are responsible for ensuring environmental security in Ukraine (Lazarenko, 2010; Budnyk, Muliavka, 2017).

Consequently, on the basis of the above-mentioned information, we have formed the proper definition of administrative-legal regulation, according to which, it represents a holistic mechanism, which is expressed in the effect of authorized state bodies on a specific group of social relations, that is, a certain object, carried out on the basis of administrative rules of law and with the help of statutory legal means. In the context of this study, such an object is the social relations in the field of the functioning of the banking system.

It should be emphasized that the category of the banking system is differently defined in the legal literature. For example, in the textbook on banking law by Kostiuchenko O.A., the banking system is considered as a part of the monetary system, an element of the economic basis of a society that develops in accordance with the laws of a market economy (Kostiuchenko, 2006). Orliuk O.P. observes a similar opinion, which indicates that the banking system is an integral part of the credit system of the state, which is a combination of different organizational and legal forms and the specialization of banking institutions operating within a single financial system and a single monetary and credit mechanism in a certain period of time (Orliuk, 2005). Fomin H.F. offers a slightly different approach to the definition of the banking system. He points out that the banking system is a legally defined set of different types of banks, through which the mobilization of funds of legal entities and individuals is carried out and various services for receiving deposits, calculations, and loans are provided to them (Fomin, 2008). Quite interesting and broad is the definition that the banking system is interpreted as complex system that belongs to a higher level and that is self-organized and historically formed under the influence of external and internal processes, is an integrated set of institutions that carry out banking activities, and banking institutions that carry out the function of internal management. This system is characterized by reactive legislative and adaptive internal ordering of links between individual elements and the external environment, as well as the ability to actively influence it and its regulatory action (Maslennikov, Sokolov, 2003; Stoiko, 2010).
Definition of the banking system also exists at the legislative level. In accordance with Article 4 of the Law of Ukraine "On Banks and Banking", the banking system of Ukraine consists of the National Bank of Ukraine and other banks, as well as branches of foreign banks established and operating in the territory of Ukraine in accordance with the provisions of the current legislation (On Banks and Banking : Law on 07.12.2000 №2121-III, 2001).

In our opinion, the legislative definition of a banking system is not entirely correct since it does not fully disclose features of this category. So, in our opinion, the banking system is not only a set of all banking institutions that are created and operate in the territory of Ukraine in accordance with the current legislation but also a set of legal relations that arise in the field of their functioning.

So, after revealing the theoretical content of the mechanism of administrative and legal regulation of the banking system, we can proceed to the analysis of its practical implementation in Ukraine and foreign countries. In the territory of our country, the National Bank of Ukraine (hereinafter - the NBU) plays a key role in the sphere of state influence and coordination of the banking system. The said body is the central bank of the state, the special central body of state administration, legal status, tasks, functions, powers, and principles of organization of which are determined by the Constitution and other legislation (On the National Bank of Ukraine : Law on 20.06.1999 №679XIV, 1999). The legislation defines quite a wide range of functions of the NBU, which, for example, includes: - ensuring the stability of the monetary unit;

- development and implementation of monetary policy; - implementation of the issue of the national currency of Ukraine on the basis of monopoly; - providing lending to banks in the last resort; - organization of the refinancing system;

- regulation of payment systems and systems of settlements in the territory of the state, determination of the order and forms of payments, including between banks;

- conducting bank regulation and supervision on individuality and on a consolidated basis, etc. (On the National Bank of Ukraine : Law on 20.06.1999 №679XIV, 1999; Constitution of Ukraine : Law on 28.06.1996 №254к/96-BP, 1996).

It should be noted that according to Article 1 of the Law of Ukraine "On the National Bank of Ukraine", the essence of the regulation of the banking system of the National Bank is to establish a system of rules governing banks, determine general principles of banking activities, the procedure for conducting banking supervision, the responsibility for violation of banking legislation (On the National Bank of Ukraine : Law on 20.06.1999 №679-XIV, 1999). The basic forms of the administrative and legal regulation of the banking system and activities of banks for today are defined: 
1) firstly, administrative regulation, which includes:

- registration of banks and licensing of their activities;

- establishment of requirements and restrictions on the activities of banks;

- application of sanctions of an administrative or financial nature;

- supervising the activities of banks;

- providing recommendations on the activities of banks;

2) secondly, indicative regulation, which includes:

- establishment of mandatory economic standards;

- definition of the standard of mandatory reserves for

banks;

- establishment of rates of deductions to reserves for covering risks from active banking operations;

- determination of interest rate policy;

- refinancing of banks;

- correspondent relations;

- management of foreign exchange reserves, including foreign exchange interventions;

- transactions in securities in the open market;

- import and export of capital.

3) thirdly, banking supervision (On Banks and Banking:

Law on 07.12.2000 №2121-III, 2001).

The latter form is undoubtedly a priority over others, taking into account the fact that the purpose of banking supervision is the stability of the banking system and the protection of interests of depositors and creditors of the bank regarding the safety of keeping customers' funds in bank accounts. In addition, the exclusive feature of the administrative and legal regulation in the form of banking supervision is confirmed by the following aspects:

- the volume of implementation, because in accordance with the law, the NBU's supervisory activities cover all banking institutions operating in the territory of Ukraine, as well as participants of banking groups abroad;

- the possibility of obtaining information, including conference, from state authorities and other persons for the purposes of banking supervision;

- the existence of the right to demand from banks and their managers, as well as banking groups, bank group participants, elimination of violations of banking legislation, implementation of regulatory acts of the NBU, etc.;

- the existence of the right to introduce a special regime of control over the activities of banks and the appointment of curators, and so on (On Banks and Banking : Law on 07.12.2000 №2121-III, 2001).

Some issues of the administrative and legal regulation of the banking system are regulated at the sub-legislative level, namely, in the provisions of the resolutions of the National Bank. The resolutions fix the number of regulations and instructions that govern specific aspects of the conduct of banking activities. They are usually of an imperative nature, that is, they require a strict compliance with certain banking institutions and bodies of the NBU.
Interesting in our opinion is the scientific view of Iskizarov O.M., who believes that along with the forms of administrative and legal regulation of the banking system established in the Law of Ukraine "On Banks and Banking" and the Law of Ukraine "On the National Bank of Ukraine", certain powers in the realization of this mechanism has the Individual Deposit Guarantee Fund. Based on the provisions of the Law of Ukraine "On Individuals' Deposit Guarantee System", the scientist emphasizes that this legal act clearly establishes and delimits the powers of the Fund and the National Bank of Ukraine regarding the procedure for withdrawal from the market and the liquidation of insolvent commercial banks. Moreover, he notes that the whole section IX of the analysed Law is devoted to the coordinating activities of the Individual Deposit Guarantee Fund and the National Bank of Ukraine, which indicates the importance of this issue (Iskizarov, 2017; On Individuals' Deposit Guarantee System : Law on 23.02.2012 №4452-VI, 2012).

Thus, the conducted analysis showed that in Ukraine, the mechanism of administrative-legal regulation of the banking system is fully consolidated within the framework of the activities of the National Bank of Ukraine, which acts as the main body in the mentioned industry. The positive point is that the legislation clearly lays down the authority of the NBU regarding the implementation of the mechanism of state influence on the banking system. Instead, some scholars point to the general imperfection of the legal framework of the latter, noting its cumbersome nature. For example, Senysh P.M. indicates that the administrative and legal regulation of the banking system is complicated, firstly, by the presence of a large number of legal acts, secondly, by frequent changes and additions to them, and thirdly, the lack of a single codified act on banking activities (Senyshch, 2014). That is, there is a situation where the powers of the relevant bodies in the field of state regulation of the banking system are legally enshrined in the provisions of several acts of various hierarchical subordinations at once. Their provisions often contradict each other, which ultimately complicates the practical implementation of the mechanism of administrative and legal regulation of the banking system as a whole.

World experience in the administrative and legal regulation of the banking system is significantly different from the national one. This, above all, is related to the fact that a large number of foreign countries built their banking systems and mechanisms of influence on them over the ages in terms of a market economy. For example, Great Britain can rightly be considered the original source of traditions in the field of administrative and legal regulation of the banking system because it was this country in 1694 where the first central bank in the world was created (Official website of the Bank of England). At the same time, for quite a long time, there was no legislative basis in Great Britain 
regarding the state regulation of the banking system. In particular, banking supervision was carried out on the basis of the Joint Stock Companies Act. The result of such a system of regulation was the emergence of large banking associations with a wide system of branches and offices in the country and abroad. Since the late 70s, the situation has begun to change, as the control and regulation of the credit and financial sector has been strengthened in the country. In accordance with the 1979 Law, the mandatory licensing of commercial banks was introduced and a nationwide deposit protection fund was established. The Banking Law of 1987 defined the rules for the activities of commercial banks, the procedure for merging banks, and introduced audits (Pavliuk, 2015; Bus, 2009). To date, the banking system of Great Britain has a well-developed infrastructure, is based on a strong money market, closely linked to the main financial centres of the world, mainly focused on servicing international economic relations. The Bank of England is a financial institution independent of the government. However, it is formally still subordinated to the Ministry of Finance (Podplietnii, 2010). The key powers of the Bank of England are:

- conducting monetary policy and issuing national currency;

- supporting the stability of the financial system;

- regulation and supervision of other banks and financial institutions (Official website of the Bank of England).

No less interesting is the mechanism of administrative and legal regulation of the banking system of the United States of America. For a long time, the state influence on the banking system in the USA was superficial and was aimed solely at securing deposits and supporting banking institutions in order to prevent the bankruptcy of the latter. This was due to the fact that in the United States until the XX century, there was virtually no central issuing bank (The Encyclopedia Americana International Edition, 1997).

To date, the administrative and legal regulation of the banking system is carried out on two levels: national and state levels. The central government body in this mechanism is the Federal Reserve System (hereinafter referred to as the FRS). It is comprised of Federal Reserve Banks, as well as the Board of Governors, serving as the key supervisory and regulatory body within the FRS. The latter in its activity implements four main functions, namely:

1) effect on the offer of money and credit;

2) regulation of activities and supervision of financial institutions;

3) the role of the bank and financial representative of the state;

4) the offer of payment services to citizens through deposit-taking institutions (The Encyclopedia Americana - International Edition, 1997; Official website of the U.S. Federal Reserve System; Buriak, 2015).
That is, unlike many European states, the banking system in the USA is regulated by the Federal Reserve System - a set of interconnected institutions, but not the only government agency in the person of the central bank.

Commercial banks in the USA are governed by state law. In addition, each commercial bank is the subject of federal regulation and supervision and also has the right to join the Federal Reserve System if it meets specific requirements. It should also be noted that the control over banks and their activities at the state level is also laid upon state departments. At the same time, in addition to special local authorities, administrative and legal influence is exercised by decisions of other federal bodies, namely: the U.S. Department of Justice (merger), the U.S. Securities and Exchange Commission (admission to the stock exchange and issue of shares), the U.S. Chamber of Commerce (servicing consumers), etc. There are also non-governmental bodies controlling the work of individual groups of credit institutions. For example, such bodies include the American Bankers Association, the Independent Community Bankers of America, and others (Buriak, 2015).

Despite the fact that the American model of administrative and legal regulation of the banking system is rather complex and, at first glance, not effective, it is this model, based on which the mechanism of state regulation of the banking system of Japan is built, of course, with a significant proportion of national characteristics. So, the Banking System of Japan consists of the Central Bank, public and private financial institutions. A group of public and private financial institutions includes city banks, trust banks, large regional banks, medium and small regional banks. The central bank manages all the banks of the country. Along with the Ministry of Finance and the Federation of Economic Organizations, it carries out monetary regulation in the country. In addition, the Bank of Japan solves three main tasks. Firstly, it forms the course of the national currency, regulating the volume of money in circulation, maintaining the stable value of the yen inside the country and abroad. Secondly, it regulates money circulation by setting interest rates. Thirdly, this is a bank that solves the problem of maintaining the stability of the country's financial system and its sustainable economic development (Shapiro, Liashenko, 2016).

One of the most perfect in the world is the German model of administrative and legal regulation of the banking system (Podplietnii, 2010; Sarkisiants, 2006). The German banking system in general consists of the Federal Bank (Bundesbank), universal banks, which include private, cooperative, and public law banks and specialized banks, which are private and public law banks. The central place in this system is occupied by the Bundesbank. It is entrusted with the implementation of regulation with the help of currency and monetary powers granted to it by law, monetary circulation and 
credit provision of the economy in order to maintain the currency stability. In addition, the Bundesbank "cares" about the banking performance of the settlement system in the country and abroad. At its disposal, there are a number of monetary and political instruments used by it independently, without interference by other agencies (Official website of the Federal Bank of Germany; Zlatina, 2010).

An important role in the mechanism of administrative and legal regulation of the banking system is played by the central landesbanken (state banks). The task of these agencies is to carry out operations and administrative management in their region. Their competence also includes the right to conclude under their responsibility for transactions with land administrations and credit institutions in their region (Melnyk, Taranhul, Hordei, 2010).

Directly administrative and supervisory powers over the banking system and its individual components in Germany are entrusted to the Federal Office of Control, which is subject to instructions and oversight by the Federal Minister of Finance. The control function is not within the competence of the Bundesbank in order to prevent administrative pressure on banks. The Office is an independent federal supreme body that manages a system of credit institutions, issues licenses for banking activities, establishes mandatory requirements for banking institutions, supervises compliance with banking legislation, and has the right to demand from banks any information, audits, interfere with operational activities, and issue orders for the immediate cessation of operations (Zlatina, 2010; Starynskyi, 2006).

The mechanism of administrative and legal regulation of the banking system in France is characterized by a high level of efficiency. The main feature of the banking system of the specified country is that it is completely under state control. French banks not only have no right to hide from the relevant public services the size and form of accounts and the movement of capital but are obliged to inform them of significant operations, especially with foreign countries (Stukalo, Lytvyn, Derkach, 2014).

A key authority in the banking system regulation is the Bank of France. The latter has the right to make regulations and to develop rules of professional activity. It is also empowered to give an opinion on all issues of credit policy, participates in the preparation and implementation of activities carried out in this area on the basis of government resolutions. Characteristic is the centralization of the entire administrative power in the hands of the head, appointed by decree. The Central Bank is traditionally the guardian of gold and foreign exchange reserves.

The main methods of monetary regulation of the economy and the banking system of France by the Central Bank are:

- accounting operations;
- open market operations;

- changes in the standards of obligatory reserves of credit institutions in the central bank;

- control over loans (Stukalo, Lytvyn, Derkach, 2014).

Along with the Bank of France, the Committee on Banking Regulation and the Banking Commission are responsible for the administrative and legal regulation of the banking system within the limits of its powers. The first body is involved in the development and adoption of legal acts on the coordination of the activities of banks and credit institutions. In essence, the Committee adopts mandatory economic standards. In turn, the Banking Commission ensures the security of the French banking system (Oksin, 2014; Bank portfolio).

\section{Conclusions}

So, having conducted a comparative analysis of the peculiarities of the mechanism of administrative and legal regulation of the banking system in the territory of Ukraine and foreign countries, we have come to a number of conclusions.

1. The national experience of state-legal influence on the banking system is based on the consolidation of powers in this area within the framework of activities of the National Bank of Ukraine. This model of administrative and legal regulation of the banking system is not generally effective and "transparent" in comparison with the foreign model and its implementation is complicated by an imperfect regulatory framework, which provisions are often contradictory.

2. An analysis of foreign experience in the administrative and legal regulation of the banking system has shown that in most countries this mechanism is focused on the distribution of powers between different state authorities. In other words, regulation of the banking system is carried out by several agencies within their authority. The purpose of this approach is to ensure the security of the banking system against the pressure from the central bank of the country.

3. At the same time, excessive allocation of powers between many public authorities can significantly impede the administrative and legal regulation of the banking system. This is most clearly expressed in the experience of the United States. The presence of a large number of regulatory governmental and nongovernmental bodies in addition to a special legal system, which has general federal and state levels, negatively affects the mechanism of state influence on the banking system, causing its bulkiness. In this regard, it is not appropriate to take over and introduce the experience of this country into the legal system of Ukraine.

As a result, it should be noted that the mechanism of administrative and legal regulation in the territory of our state should be changed. In this context, the experience of Germany and France where regulatory 
and control powers are shared between the central bank and other government departments, which, in turn, reduces the risk of administrative pressure on individual banking institutions and the banking system as a whole, is most appropriate for implementation. In addition, the construction of an efficient and effective mechanism of administrative and legal regulation of the banking system requires systematization of the current legislation in this area, in order to eliminate contradictions and gaps.

\section{References:}

Bilodid I.K. (1977). Dictionary of the Ukrainian language : in 11 Volumes. Kyiv : "Naukova Dumka”. Volume 8. P. 480. [Electronic resource]. Retrieved from: http://sum.in.ua/p/8/480/2

Explanatory Dictionary of Contemporary Ukrainian Language (2005). L.P. Kovryha, T.V. Kovalova, V.D. Ponomarenko; under the general editorship of V.S. Kalashnyk. Kharkiv : Belkar-Knyha, 800 p.

Shemshuchenko Yu.S. (1998). Legal Encyclopaedia : in 6 Vols. K.: “Ukrainian Encyclopedia”. Vol. 5, 736 p.

Busel V.T. (2005). Great Interpretative Dictionary of Modern Ukrainian Language. K.; Irpin : PTF “Perun”, 1728 p. Alforov S.M., Vashchenko S.V., Dolhopolova M.M., Kupin A.P. (2011). Administrative law. General part. Study guide. K.: Tsentr Uchbovoi Literatury, 216 p.

Malko A.V., Matuzov N.I. (2004). Theory of state and law : textbook. M.: Yurist, 512 p.

Holosnichenko I.P., Stakhurskyi M.F. (2005). Administrative law of Ukraine : basic concepts : study guide. K.: HAN, 231 p.

Valkova Ye.V. (2012). The essence and structure of the mechanism of administrative-legal regulation in the field of intellectual property rights protection. Forum Prava. №3, p. 84-88.

Kozlov Yu.M. (2002). Administrative law : textbook for students of HEI studying in the specialty "Jurisprudence”. M.: Yurist, 697 p.

Khomiachenko S.I., Yeriashov Ye.K. (2014). Features of the mechanism of administrative-legal regulation of civil aviation. Law Herald. №2(31), p. 10-13.

Lazarenko V.A. (2010). The genesis of administrative and legal regulation of environmental security in Ukraine. Yurydychnyi Visnyk. №1(8), p. 122-132.

Budnyk Yu.A., Muliavka D.H. (2017). The concept and essence of administrative and legal regulation of managing the system of professional orientation in Ukraine. Juridical Scientific and Electronic Journal. №3, p. 81-82.

Kostiuchenko O.A. (2006). Banking law of Ukraine : textbook. K.: A.S.K., 624 p.

Orliuk O.P. (2005). Banking law : study guide. K.: Yurinkom Inter, 376 p.

Fomin H.F. (2008). Banking law of Ukraine : study guide. Publishing house of Kharkiv National University of Internal Affairs, $360 \mathrm{p}$.

Maslennikov V.V., Sokolov Yu.A. (2003). National banking system. M. : TD “Elit-2000”, 256 p.

Stoiko V.S. (2010). Theoretical approaches to the definition of the essence of the banking system and its role in the country's economy. Uzhhorod University Scientific Herald. Iss. 30, p. 202-209.

On Banks and Banking : Law on 07.12.2000 №2121-III (2001). Gazette of the Verkhovna Rada of Ukraine. №5. Art. 30. On the National Bank of Ukraine : Law on 20.06.1999 №679-XIV (1999). Gazette of the Verkhovna Rada of Ukraine. №29. Art. 238.

Constitution of Ukraine : Law on 28.06.1996 №254к/96-BP (1996). Gazette of the Verkhovna Rada of Ukraine. №30. Art. 141.

Iskizarov O.M. (2017). Administrative-legal regulation of banking activity in Ukraine : thesis. Zaporizhzhia : Classic Private University, 235 p.

On Individuals' Deposit Guarantee System : Law on 23.02.2012 №4452-VI (2012). Gazette of the Verkhovna Rada of Ukraine. №50. Art. 564.

Senyshch P.M. (2014). Legal instruments for regulating the development of banking activities in Ukraine. Business Inform. № 3, p. 325-329.

Official website of the Bank of England [Electronic resource]. Retrieved from: https://www.bankofengland.co.uk/ about/history

Pavliuk O.O. (2015). Experience of foreign countries in the application of banking supervision and regulation. External policy and diplomacy : traditions, trends, experience. Iss.22. Part 3, P. 216-222.

Bus O.B. (2009). Features of the organization of banking supervision, control, and regulation in foreign countries. Scientific Bulletin of UNFU. Iss.19.2, p. 163-172.

Podplietnii V.V. (2010). Improvement of banking activities in the context of features of the functioning of banking systems of European counties The Collection of Scientific Works of Kirovohrad National Technical University. Economic Sciences. Issue 18, part 1, p. 291-297.

The Encyclopedia Americana - International Edition (1997), p. 182.

Official website of the U.S. Federal Reserve System [Electronic resource]. Retrieved from: https: //www.federalreserve.gov/ 
Buriak O.P. (2015). The banking system of the USA. Sustainable Development of Economy. №26, p. 233-238.

Shapiro V.S., Liashenko V.V. (2016). Building and functioning of banking systems : foreign experience. Young Scientist. №12(39), p. 626-629.

Sarkisiants A.G. (2006). Formation of new world banking industry. Auditor. №6. [Electronic resource]. Retrieved from: //www.gaap.ru/biblio/audit/auditor/0606_02.asp

Official website of the Federal Bank of Germany [Electronic resource]. Retrieved from: http://www.bundesbank.de Zlatina N. (2010). Features of banking systems of foreign countries (the case of France, Germany, Italy, and Switzerland). Bulletin of Taras Shevchenko National University of Kyiv. №84, p. 90-93.

Melnyk P.V., Taranhul L.L., Hordei O.D. (2010). Banking systems of foreign countries: textbook. K., p. 181.

Starynskyi M.V. (2006). Comparative banking law: study guide. Sumy, p. 137.

Stukalo N.V., Lytvyn M.V., Derkach M.I. (2014). Global finance : study guide. Dnipropetrovsk, 1092 p.

Oksin V.Yu. (2014). Foreign experience in the administrative and legal regulation of the banking system. Mytna sprava. №5, Part 2, Book 1, p. 9-13.

Bank portfolio (The banker's book. The client's book. The investor's book) EiC Korobov Yu.I., Soldatkin V.I. (1994). M.: SOMITEK, $750 \mathrm{p}$. 